\title{
Maternal and child health inequalities among migrants: the case of Haiti and the Dominican Republic
}

\author{
Roberta Bouilly, ${ }^{1}$ Giovanna Gatica-Domínguez, ${ }^{1}$ Marilia Mesenburg, ${ }^{1,2}$ Francisco I. Cáceres Ureña ${ }^{3,4}$ \\ Daniel G. P. Leventhal, ${ }^{1}$ Aluísio J. D. Barros, ${ }^{1}$ Cesar G. Victora ${ }^{1}$ and Fernando C. Wehrmeister ${ }^{1}$
}

Suggested citation Bouilly R, Gatica-Domínguez G, Mesenburg M, Cáceres Ureña FI, Leventhal DGP, Barros AJD et al. Maternal and child health inequalities among migrants: the case of Haiti and the Dominican Republic. Rev Panam Salud Publica. 2020;44:e144 https://doi.org/10.26633/RPSP.2020.144

ABSTRACT Objective. To assess coverage and inequalities in maternal and child health interventions among Haitians, Haitian migrants in the Dominican Republic and Dominicans.

Methods. Cross-sectional study using data from nationally representative surveys carried out in Haiti in 2012 and in the Dominican Republic in 2014. Nine indicators were compared: demand for family planning satisfied with modern methods, antenatal care, delivery care (skilled birth attendance), child vaccination (BCG, measles and DPT3), child case management (oral rehydration salts for diarrhea and careseeking for suspected pneumonia), and the composite coverage index. Wealth was measured through an asset-based index, divided into tertiles, and place of residence (urban or rural) was established according to the country definition.

Results. Haitians showed the lowest coverage for demand for family planning satisfied with modern methods $(44.2 \%)$, antenatal care $(65.3 \%)$, skilled birth attendance $(39.5 \%)$ and careseeking for suspected pneumonia $(37.9 \%)$, and the highest for oral rehydration salts for diarrhea (52.9\%), whereas Haitian migrants had the lowest coverage in DPT3 (44.1\%) and oral rehydration salts for diarrhea (38\%) and the highest in careseeking for suspected pneumonia (80.7\%). Dominicans presented the highest coverage for most indicators, except oral rehydration salts for diarrhea and careseeking for suspected pneumonia. The composite coverage index was $79.2 \%$ for Dominicans, $69.0 \%$ for Haitian migrants, and $52.6 \%$ for Haitians. Socioeconomic inequalities generally had pro-rich and pro-urban pattern in all analyzed groups.

Conclusion. Haitian migrants presented higher coverage than Haitians, but lower than Dominicans. Both countries should plan actions and policies to increase coverage and address inequalities of maternal health interventions.

Keywords Human migration; maternal health; child health; healthcare disparities; Haiti; Dominican Republic.

Migration is a universal phenomenon that implies movement from one geographical area to another, and is regarded as one of the four mechanisms of biological evolution (1). In 2015, nearly 250 million people worldwide migrated, almost half of whom were women $(2,3)$. In Latin America and the Caribbean, just under 25 million people migrated to the United States and 4.6 million to Europe in 2015. In addition to such well-described interregional migration, the migration flow from Haiti to the Dominican Republic represents one of the most prominent intraregional migration routes in the Caribbean (2). The United Nations reported that the number of Haitians who migrated to the Dominican Republic in 2015 was 329281 and this number was $57 \%$ more than what was reported in $1990(4)$.

\footnotetext{
1 Federal University of Pelotas, Pelotas, Brazil. $\triangle$ Fernando C. Wehrmeister, fwehrmeister@equidade.org

2 Federal University of Health Science, Porto Alegre, Brazil
} 
The reasons for such migration include political instability, persistently precarious economic situation and frequent natural disasters in Haiti (5). According to the first survey of immigrants in the Dominican Republic (ENI-2012), 5.4\% of the total population of the country were migrants. From these, $87.3 \%$ were born in Haiti, revealing the predominance of Haitian migrants in the country (6).

Haitian women have always been present in immigration flows to their neighboring country (6). Initially, they went as companions to the male workforce (7). Yet, many of them have limited access to sexual and reproductive health services in the Dominican Republic, as they may not have the necessary documentation or have their rights denied (8). This situation may negatively affect the physical and emotional health of immigrant women and their children, placing them in a greater position of vulnerability.

Goal 10.7 of the Sustainable Development Goals stresses the facilitation of "orderly, safe, and responsible migration and mobility of people, including through implementation of planned and well-managed migration policies" (https://www. un.org/sustainabledevelopment/sustainable-developmentgoals/). Despite the continuing movement of migrants from Haiti to the Dominican Republic, little is known about how migrant status influences their coverage with reproductive, maternal, newborn and child health (RMNCH) interventions. The aim of this study was to assess coverage and inequalities in maternal and child health interventions, by comparing Haitian migrant women and their children living in the Dominican Republic with Haitians and Dominicans living in their respective countries.

\section{MATERIALS AND METHODS}

This is a cross-sectional study, using data from nationally representative surveys carried out in Haiti in 2012 (Demographic and Health Surveys, DHS) and in the Dominican Republic in 2014 (Multiple Indicator Cluster Surveys, MICS, http://mics.unicef.org/). Both surveys collected standardized information regarding household, individual and community characteristics, allowing comparison between the countries (9). Information collected from women aged 15 to 49 years and their under-five children was analyzed.

\section{Coverage indicators}

Nine maternal and child health intervention indicators were analyzed. These indicators followed the Countdown to 2030 (http://countdown2030.org) definitions and are: 1) Demand for family planning satisfied with modern methods (DFPSm): proportion of women aged 15 to 49 years currently married or in union in need of contraception that are using (or whose partner is using) a modern contraception method; 2) Four or more antenatal care visits (ANC4): proportion of women aged 15 to 49 years and who gave birth in the three (DHS) or two (MICS) preceding years of the surveys that have at least four antenatal care visits; 3) Skilled birth attendance (SBA): proportion of women aged 15 to 49 years old who gave birth in the three (DHS) or two (MICS) preceding years of the surveys whose delivery was assisted by a skilled attendant; 4) BCG immunization (BCG): proportion of live children between 12-23 months of age who received BCG (Bacillus Calmette-Guerin) immunization; 5) DPT3 immunization (DPT3): proportion of children between 12-23 months of age who received three doses of DPT (diphtheria, pertussis and tetanus) immunization; 6) Measles immunization (MSL) proportion of children between 12-23 months of age who received measles immunization (monovalent or not); 7) Careseeking for suspected pneumonia (CAREP): proportion of live under-five children with suspected pneumonia in the last two weeks that sought treatment from an appropriate health facility or provider; 8) Oral rehydration salts for diarrhea (ORS): proportion of live under-five children with diarrhea in the last two weeks that received oral rehydration therapy (packets of oral rehydration salts, recommended home solution, or increased fluids); and 9) Composite coverage index $(\mathrm{CCI})$ : weighted average of the eight indicators mentioned above, related to the continuum of care. The CCI was initially proposed by Boerma et al. in 2008 (10) and updated by the Countdown to 2030 (11) as follows:

$$
C C I=\frac{1}{4}\left(\begin{array}{l}
D F P S m+\frac{A N C 4+\mathrm{SBA}}{2}+ \\
\frac{\mathrm{BCG}+2 \times D P T 3+M S L}{4}+\frac{O R S+C A R E P}{2}
\end{array}\right)
$$

All indicators used in the present analyses have been standardized at the International Center for Equity in Health (ICEH; www.equidade.org), allowing for comparisons between the two surveys. The standardization procedures ensure that indicator definitions, their numerators and denominators are consistent across surveys.

\section{Migratory status}

Migratory status was defined according to the primary language spoken by the woman or the household head. Women and children were classified into three groups: 1) Haitians: those who were included in the Haiti DHS survey; 2) Dominicans: those who were included in the Dominican Republic MICS survey and indicated Spanish as their primary language; and 3) Haitian migrants: those who were included in the Dominican Republic MICS survey and had creole as their primary language, given that this is the main language spoken by migrants and one of the officials languages in Haiti.

\section{Stratifiers}

Two additional variables were included in the analyses: place of residence and the wealth index. Place of residence was divided into urban and rural, according to each country's definitions. The wealth index is based on each household's assets. It is calculated through a principal component analysis and differences among assets in urban and rural residence are considered in its score. Details on the wealth index calculation can be found elsewhere (12). Due to sample size limitations, the score was divided into tertiles, where the first tertile (T1) represents the one third poorest group in the sample and the third tertile (T3) represents the one third wealthiest. Wealth indices were calculated separately for each of the two surveys.

\section{Data analysis}

Socioeconomic and demographic characteristics of the two countries were obtained from the World Bank database 
(https://data.worldbank.org) and the Index Mundi (https:/ / www.indexmundi.com), both searched in January 2020, in order to provide a brief description of these countries.

Coverage of the nine indicators studied and their respective $95 \%$ confidence interval $(95 \% \mathrm{CI})$ were estimated for each of the three groups of migratory status taking into account the sample design. The analyses were also stratified by wealth index tertiles and place of residence, within the migratory groups.

The slope index of inequality (SII), a complex measure of absolute inequality, was calculated for each indicator based on logistic regression. The SII represents the absolute difference in percentage points (pp) based on the predicted values for a given indicator, between upper and lower extremes of the socioeconomic spectrum. The SII may range from -100 to 100 $\mathrm{pp}$. A value of zero indicates that there is no inequality; positive values indicate that the coverage is higher among the wealthiest individuals, while the opposite is true for negative values. All analyses were carried out using Stata version 15.1 (StataCorp LP, College Station, Texas, United States).

\section{Ethical aspects}

Ethical approval for each survey was obtained by the responsible agencies. The data used in the analyses are anonymized and publicly available, by the MICS and DHS teams.

\section{Results}

Table 1 shows the socioeconomic and demographic characteristics of Haiti and the Dominican Republic. The geographic area of the latter is almost double that of Haiti, but with a

TABLE 1. Demographic and socioeconomic characteristics of Haiti and Dominican Republic

\begin{tabular}{|c|c|c|}
\hline & Haiti & Dominican Republic \\
\hline Total area $\left(\mathrm{km}^{2}\right)$ & 27560 & 48310 \\
\hline Rural & $26163(94.9 \%)$ & $42784(88.6 \%)$ \\
\hline Total population & 9801664 & 10349740 \\
\hline $\begin{array}{l}\text { Population density } \\
\text { (inhabitants } / \mathrm{km}^{2} \text { ) }\end{array}$ & 353.2 & 212.7 \\
\hline $\begin{array}{l}\text { Demographic growth } \\
\text { (mean annual percentage growth) }\end{array}$ & 0.9 & 1.3 \\
\hline Life expectancy & 62.5 & 77.8 \\
\hline Birth rate (per 1000$)$ & 23.9 & 19.0 \\
\hline General mortality rate (per 1000 ) & 8.1 & 4.5 \\
\hline $\begin{array}{l}\text { Liquid migration rate } \\
\text { (immigration - emigration, } \\
\text { per } 1000 \text { ) }\end{array}$ & -6.9 & -1.9 \\
\hline Infant mortality rate (per 1000 ) & 52.4 & 19.6 \\
\hline $\begin{array}{l}\text { Maternal mortality rate } \\
\text { (per } 100000)\end{array}$ & 359 & 92 \\
\hline Literacy rate & 60.7 & 91.8 \\
\hline $\begin{array}{l}\text { Per capita gross domestic product } \\
\text { (GDP) (US\$, adjusted for power } \\
\text { purchasing parity) }\end{array}$ & 1300 & 9700 \\
\hline $\begin{array}{l}\text { Gross domestic product (GDP), } \\
\text { growth rate (annual percentage } \\
\text { change, adjusted by monetary } \\
\text { inflation) }\end{array}$ & 2.8 & 2.0 \\
\hline
\end{tabular}

smaller demographic density. The liquid migration rate, which is calculated subtracting the number of people emigrating from those that immigrated, is lower in Haiti (-6.9 per thousand inhabitants), than in the Dominican Republic (-1.9 per thousand inhabitants), indicating that more Haitians emigrate than people immigrate to the country. Overall, demographic (life expectancy and mortality rates) and socioeconomic (GDP per capita and literacy) indicators are better in the Dominican Republic than in Haiti.

Figure 1 shows the coverage of $\mathrm{RMNCH}$ interventions for Haitians, Haitians migrants and Dominicans. Dominican women and children presented the highest coverage of the three groups for most indicators, ranging from $49.0 \%$ for oral rehydration salts for diarrhea to $98.6 \%$ for skilled birth attendant, with almost none overlap between the $95 \%$ confidence interval. Dominicans had lower coverage of careseeking for suspected pneumonia than Haitian migrants $(71.8 \%$ and $80.7 \%$, respectively). Haitians presented the lowest coverage of demand for family planning satisfied, four or more antenatal care visits, skilled birth attendant, BCG immunization and careseeking for suspected pneumonia than the other groups, but the highest coverage of oral rehydration salts for diarrhea. Vaccination coverage (measles-containing vaccine and three doses of DPT) and oral rehydration salts for diarrhea was lowest among Haitian migrants. The summary index of $\mathrm{RMNCH}$ interventions, composite coverage index, was $79.2 \%$ for Dominicans, $69.0 \%$ for Haitian migrants, and $52.6 \%$ for Haitians.

Figure 2 presents the coverage of $\mathrm{RMNCH}$ indicators by wealth tertiles for each group. In general, women and children belonging to the wealthiest tertile presented higher coverage when compared to those belonging to the poorest tertile. Positive SII values indicate pro-rich coverage patterns. For six of the nine indicators, Haitians presented the highest SII, whereas Dominicans presented the lowest SII for five of the indicators. The highest pro-rich inequality was observed for skilled birth attendant among Haitians (SII $=74.2 \mathrm{pp}$ ). Sample sizes and $95 \%$ confidence intervals for these measures are presented in Table 2.

The coverage of $\mathrm{RMNCH}$ indicators according to migratory status and place of residence, and the absolute urban-rural difference in percentage points are shown in Figure 3. In general, inequalities have a pro-urban pattern. Haitians presented the largest pro-urban inequalities for four or more antenatal care visits and skilled birth attendant coverages (13.6 pp and $35.0 \mathrm{pp}$, respectively), whereas Haitian migrants showed the largest pro-urban inequalities for measles and DPT3 vaccination (18.9 pp and $11.0 \mathrm{pp}$, respectively). Urban-rural inequalities of the composite coverage index were higher for Haitians and Haitian migrants (9.0 pp and $5.3 \mathrm{pp}$, respectively) than for Dominicans (-0.4 pp). Table 2 presents the sample sizes and $95 \%$ confidence intervals by urban or rural residence.

\section{DISCUSSION}

The results indicate that, in general, coverage among Haitian migrant women and children in the Dominican Republic is higher than among Haitians who reside in their home country. Yet, despite residing in the same country, Haitian migrants are still behind Dominicans in terms of coverage. Inequalities were found among Haitians and Haitian migrants, but the former presented wider disparities for most indicators. 
FIGURE 1. Coverage of RMNCH indicators among Haitians, Haitian migrants and Dominicans

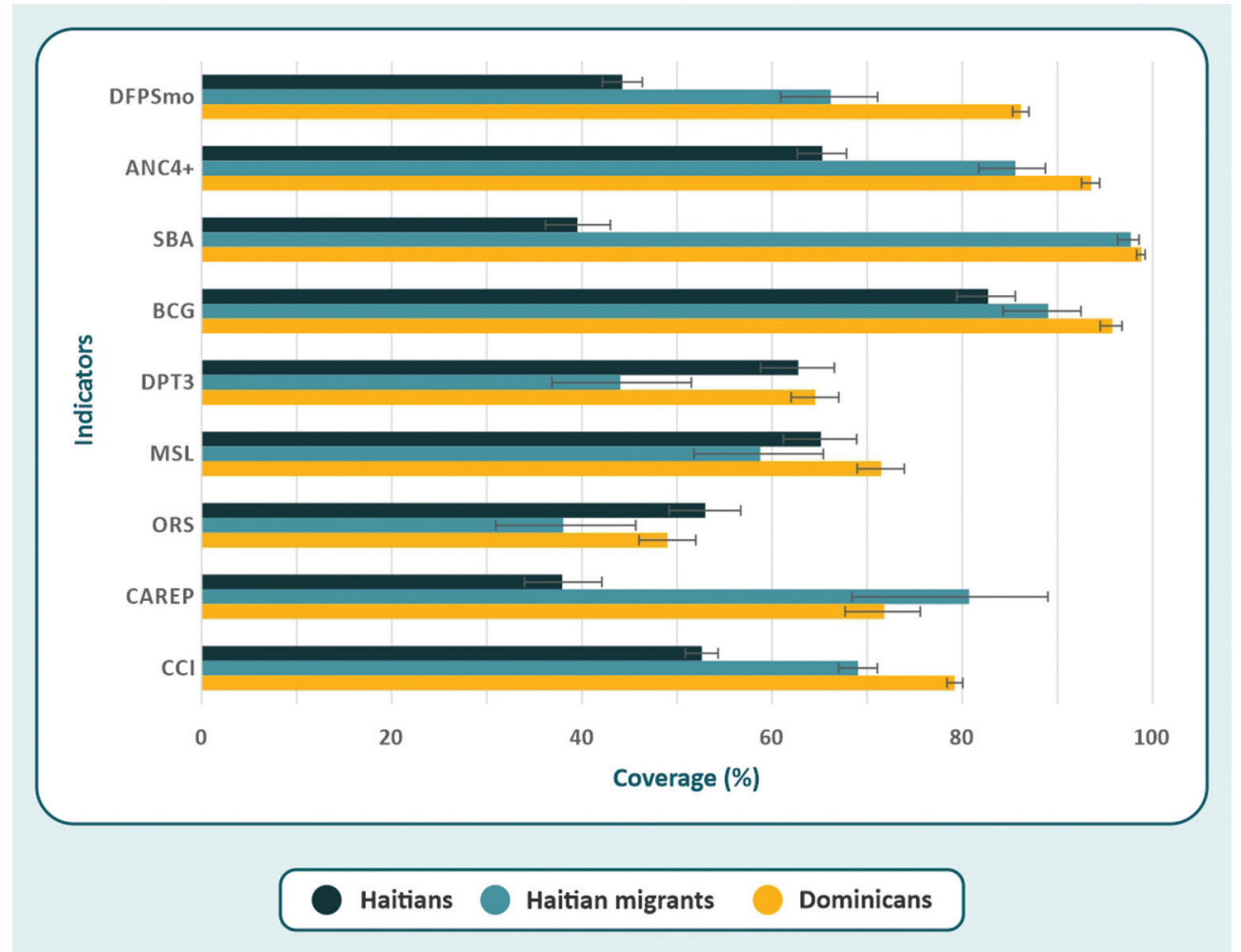

DFPSm, demand for family planning satisfied with modern methods; ANC4, at least 4 antenatal care visits; SBA, skilled birth attendance; BCG, BCG immunization; MSL, measles immunization; DPT3, three doses of DPT immunization; ORS, oral rehydration salts for diarrhea; CAREP, careseeking for suspected pneumonia; CCI, composite coverage index.

In 2001, the Dominican Republic government approved a structural reform for the health system (Law 87-01), which included a package of benefits for the entire population in order to achieve universal and equitable coverage reflecting an inclusive health model. The health reform established that the poor would be subsidized through per capita payments from general taxes (13). This may partially explain the higher RMNCH coverage observed in the Dominican Republic, both for native and immigrant women and children.

In contrast, only half of the Haitian population has regular access to health care, mainly due to widespread poverty, a shortage of health care professionals in the country (14), chronic underinvestment in the health infrastructure and political instability (5).

To compound the pre-existing crisis, the major 2010 earthquake compromised access to basic services in Haiti, such as health care, education, and drinking water, as well as employment and other income opportunities (15). After a natural disaster, disruptions in health services can occur and negatively affect routine services providing $\mathrm{RMNCH}$ interventions, by a shift in medical priorities towards emergency care (5). After the earthquake, foreign humanitarian aid increased sharply, including substantial donations of financial resources and medical supplies by international institutions. Tohme et al. found that Haiti significantly improved its vaccination services and vaccine-preventable diseases surveillance during the period between 2010 and 2016 (16). This may explain the higher coverage of three doses of DPT and measles-containing vaccines among Haitian children comparing Haitian migrants. Vaccination is a relatively straightforward intervention to offer at the community level, not requiring complex infrastructure such as other interventions like institutional delivery.

In general, the literature has shown that migrant women have worse health coverage than residents of the receiving country (17-19). Possible reasons include language barriers (especially upon arrival), discrimination, lack of documentation, transportation costs, and distance between place of residence and health services, among others (20-24). For example, the possession of personal documents is essential for everyone, even more so for immigrants. In the absence of these documents, immigrants may face restrictions on access to medical care, education and labor mobility in the country $(6,8,22)$. Those factors may lead individuals to seek emergency services instead of primary-care-based preventive health services, as has been observed in other migratory contexts (25).

Acculturation is an important social construct that elucidates the determinants and consequences of health disparities in minority populations (26) because it is a process through which immigrants internalize the culture by adopting the norms, values, and practices of their new place of residence (23). Therefore, the fact that $\mathrm{RMNCH}$ coverage in Haitian migrants is lower than among Dominicans but higher than among Haitians, could be partially due to some level of acculturation among migrants and better quality of health care provided to migrants than what is available in Haiti. Unfortunately, it was not possible to better explore the level of acculturation in our study due to lack 
FIGURE 2. Coverage for RMNCH indicators according to migratory status and wealth tertiles

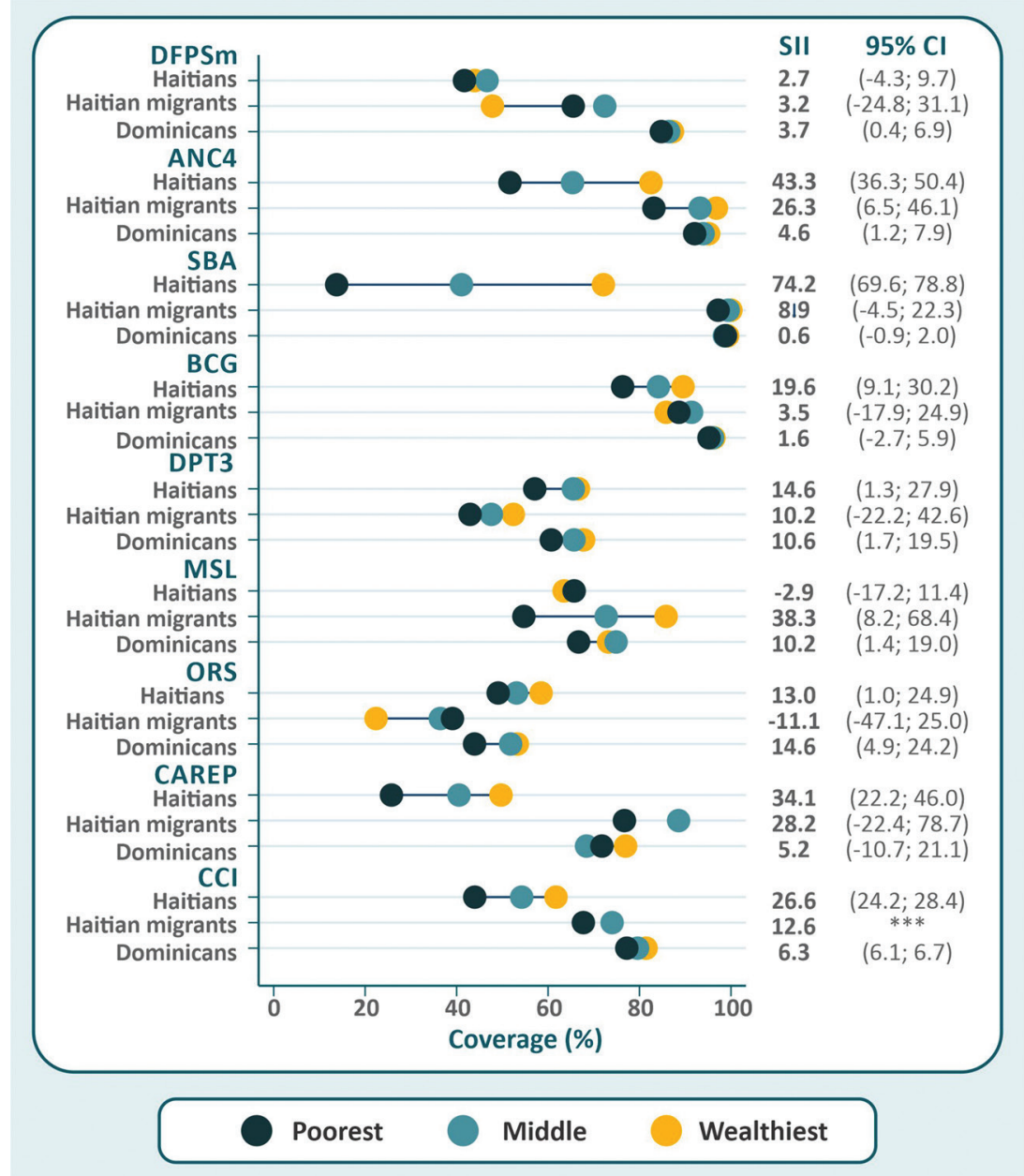

DFPSm, demand for family planning satisfied with modern methods; ANC4, at least 4 antenatal care visits; SBA, skilled birth attendance; BCG, BCG immunization; MSL, measles immunization; DPT3, three doses of DPT immunization; ORS, oral rehydration salts for diarrhea; CAREP, careseeking for suspected pneumonia; $\mathrm{CCl}$, composite coverage index.

of information on the time elapsed between immigration to the Dominican Republic and the time the survey was conducted.

Two coverage indicators deserve special attention, oral rehydration salts for diarrhea and pneumonia careseeking. Access to safe water can be jeopardized by natural disasters, with increased risk of diarrheal disease outbreaks (27). After the 2010 earthquake there was a cholera outbreak, centered in rural areas of Haiti. The response to the epidemic included community-based distribution of oral rehydration salts and water-purification systems, and education on hygiene practices, among other interventions. One of the five basic messages spread in the media at this time was to give oral rehydration salts to anyone with diarrhea $(14,28,29)$, in addition to widespread provision of oral rehydration salts packages by the government and voluntary organizations. This may explain why oral rehydration salts use was higher in Haiti than in the Dominican Republic, where the epidemic was less severe among natives and immigrants (14).

Pneumonia careseeking was the only indicator for which Haitian migrants presented the highest coverage. However, this result must be interpreted carefully, since this specific indicator had the smallest sample size $(\mathrm{N}=67)$, being the only one with fewer than 100 women or children in the denominator. The $95 \%$ confidence interval for this estimate ranged from $68.4 \%$ to $88.9 \%$.

Both place of residence and wealth may play an important role in coverage of maternal and child health interventions. Inequalities in $\mathrm{RMNCH}$ coverage usually show pro-rich and pro-urban patterns (30). Evidence indicates that preexisting socioeconomic inequalities are often exacerbated by disasters (5), which may explain why disparities were so wide in Haiti. Rural residence affects access to adequate health facilities due to geographic and economic barriers $(31,32)$. In this study, women and children living in urban areas presented the higher coverage than those from rural areas, in the three groups studied. The urban-rural gap was narrower among Dominicans, likely reflecting the existence of a more structured and decentralized health system in the Dominican Republic (13), with fewer barriers to access for Dominicans as well as for Haitian migrants, than is the case of Haitians living in Haiti (33).

The disaggregated analyses by both migration status and wealth allowed the assessment of intersectionality. These results suggest that wealth-related inequalities are much wider in Haiti than among either Dominicans or migrants in the Dominican 
TABLE 2. Sample sizes and $95 \%$ confidence interval for each of the indicators, according to migratory status, by wealth tertiles and area of residence.

\begin{tabular}{|c|c|c|c|c|c|c|c|}
\hline \multirow{2}{*}{ Indicators } & \multirow{2}{*}{ Groups } & & \multicolumn{3}{|c|}{ Wealth tertiles } & \multicolumn{2}{|c|}{ Place of residence } \\
\hline & & & Poorest & Middle & Wealthiest & Urban & Rural \\
\hline \multicolumn{8}{|c|}{ Women } \\
\hline \multirow{5}{*}{$\begin{array}{l}\text { Demand for family } \\
\text { planning satisfied } \\
\text { (modern methods) }\end{array}$} & Haitians & N & 1974 & 2075 & 1521 & 2248 & 3323 \\
\hline & & Estimate $95 \% \mathrm{Cl}$ & $38.3 ; 35.2$ & $43.2 ; 50.2$ & $40.8 ; 47.2$ & $41.3 ; 47.3$ & $41.3 ; 47.2$ \\
\hline & Haitian Immigrants & $\mathrm{N}$ & 771 & 102 & 19 & 402 & 491 \\
\hline & Dominicans & $\mathrm{N}$ & 5290 & 4304 & 3607 & 8463 & 4738 \\
\hline & & Estimate $95 \% \mathrm{Cl}$ & $83.2 ; 86.2$ & $84.8 ; 87.8$ & $85.6 ; 88.7$ & $84.7 ; 86.7$ & $85.9 ; 88.8$ \\
\hline \multirow[t]{4}{*}{ 4+ antenatal care visits } & Haitians & $\mathrm{N}$ & 1701 & 1480 & 862 & 1393 & 2650 \\
\hline & & Estimate $95 \% \mathrm{Cl}$ & $47.7 ; 55.7$ & $61.9 ; 68.6$ & $78.8 ; 85.7$ & $70.2 ; 77.2$ & $56.7 ; 63.7$ \\
\hline & Haitian Immigrants & $\mathrm{N}$ & 598 & 70 & 15 & 322 & 361 \\
\hline & & Estimate $95 \% \mathrm{Cl}$ & $78.6 ; 86.9$ & $84.0 ; 97.3$ & $77.4 ; 99.6$ & $82.3 ; 90.5$ & $76.6 ; 88.9$ \\
\hline \multirow{6}{*}{ Skilled birth attendant } & & Estimate $95 \% \mathrm{Cl}$ & $11.5 ; 16.4$ & $37.4 ; 44.8$ & $67.8 ; 76.1$ & $57.1 ; 66.2$ & $23.2 ; 30.6$ \\
\hline & Haitian Immigrants & $\mathrm{N}$ & 598 & 70 & 15 & 322 & 361 \\
\hline & & Estimate $95 \% \mathrm{Cl}$ & $95.4 ; 98.3$ & $95.8 ; 99.9$ & * & $96.7 ; 99.3$ & $93.8 ; 98.2$ \\
\hline & Dominicans & $\mathrm{N}$ & 3033 & 2154 & 1628 & 4538 & 2277 \\
\hline & & Estimate $95 \% \mathrm{Cl}$ & $97.9 ; 99.3$ & $97.4 ; 99.2$ & $98.2 ; 99.7$ & $98.2 ; 99.4$ & $97.7 ; 99.1$ \\
\hline & & & Idren & & & & \\
\hline \multirow[t]{5}{*}{$B C G$ vaccine } & Haitians & $\mathrm{N}$ & 567 & 518 & 285 & 471 & 899 \\
\hline & & Estimate $95 \% \mathrm{Cl}$ & $70.2 ; 81.6$ & $79.4 ; 88.0$ & $85.0 ; 92.8$ & $83.5 ; 90.8$ & $75.3 ; 83.9$ \\
\hline & Haitian Immigrants & $\mathrm{N}$ & 296 & 43 & 8 & 171 & 176 \\
\hline & & Estimate $95 \% \mathrm{Cl}$ & $83.3 ; 92.2$ & $74.1 ; 97.5$ & $41.5 ; 98.1$ & $82.8 ; 94.3$ & $80.6 ; 92.4$ \\
\hline & Dominicans & $\mathrm{N}$ & 1454 & 1077 & 837 & 2246 & 1132 \\
\hline \multirow[t]{6}{*}{ DPT vaccine (three doses) } & Haitians & $\mathrm{N}$ & 567 & 518 & 285 & 471 & 899 \\
\hline & & Estimate $95 \% \mathrm{Cl}$ & $50.3 ; 63.6$ & $59.7 ; 71.0$ & $60.1 ; 72.6$ & $59.1 ; 70.7$ & $56.2 ; 66.4$ \\
\hline & Haitian Immigrants & $\mathrm{N}$ & 285 & 43 & 8 & 167 & 169 \\
\hline & & Estimate $95 \% \mathrm{Cl}$ & $35.1 ; 51.2$ & $30.6 ; 65.2$ & $18.9 ; 83.9$ & $38.4 ; 58.8$ & $28.3 ; 47.6$ \\
\hline & Dominicans & $\mathrm{N}$ & 1422 & 1059 & 825 & 2201 & 1105 \\
\hline & & Estimate $95 \% \mathrm{Cl}$ & $56.8 ; 64.5$ & $61.2 ; 69.8$ & $62.9 ; 72.3$ & $60.0 ; 66.0$ & $64.3 ; 73.3$ \\
\hline \multirow[t]{6}{*}{ Oral rehydration salts } & Haitians & $\mathrm{N}$ & 596 & 565 & 254 & 488 & 927 \\
\hline & & Estimate $95 \% \mathrm{Cl}$ & $43.7 ; 54.5$ & $47.1 ; 59.0$ & $51.4 ; 65.3$ & $50.2 ; 62.2$ & $46.2 ; 55.6$ \\
\hline & Haitian Immigrants & $\mathrm{N}$ & 276 & 37 & 6 & 156 & 163 \\
\hline & & Estimate $95 \% \mathrm{Cl}$ & $31.2 ; 47.6$ & $20.0 ; 56.8$ & $4.9 ; 61.8$ & $28.2 ; 46.8$ & $28.3 ; 52.2$ \\
\hline & Dominicans & $\mathrm{N}$ & 1500 & 969 & 609 & 2063 & 1015 \\
\hline & & Estimate $95 \% \mathrm{Cl}$ & $40.4 ; 47.6$ & $45.9 ; 57.7$ & $47.7 ; 59.0$ & $47.2 ; 54.4$ & $38.5 ; 47.5$ \\
\hline \multirow[t]{6}{*}{ Careseeking for pneumonia } & Haitians & $\mathrm{N}$ & 433 & 373 & 202 & 332 & 676 \\
\hline & & Estimate $95 \% \mathrm{Cl}$ & $20.4 ; 32.0$ & $34.4 ; 46.9$ & $42.9 ; 56.5$ & $38.7 ; 50.2$ & $29.1 ; 39.8$ \\
\hline & Haitian Immigrants & $\mathrm{N}$ & 53 & 14 & ** & 34 & 33 \\
\hline & & Estimate $95 \% \mathrm{Cl}$ & $61.1 ; 87.4$ & $64.0 ; 97.1$ & ** & $71.2 ; 94.2$ & $48.4 ; 84.0$ \\
\hline & Dominicans & $\mathrm{N}$ & 491 & 365 & 192 & 715 & 333 \\
\hline & & Estimate $95 \% \mathrm{Cl}$ & $65.8 ; 77.1$ & $62.0 ; 74.2$ & $65.5 ; 85.5$ & $66.3 ; 75.7$ & $66.8 ; 79.9$ \\
\hline
\end{tabular}


TABLE 2. Sample sizes and $95 \%$ confidence interval for each of the indicators, according to migratory status, by wealth tertiles and area of residence. (Cont.)

\begin{tabular}{|c|c|c|c|c|c|c|c|}
\hline \multirow{2}{*}{ Indicators } & \multirow{2}{*}{ Groups } & & \multicolumn{3}{|c|}{ Wealth tertiles } & \multicolumn{2}{|c|}{ Place of residence } \\
\hline & & & Poorest & Middle & Wealthiest & Urban & Rural \\
\hline \multicolumn{8}{|c|}{ Combined indicator } \\
\hline \multirow[t]{3}{*}{ Composite coverage index } & Haitians & N & $\star \star \star$ & $* * *$ & $* \star *$ & $* * *$ & $\star \star *$ \\
\hline & Haitian Immigrants & N & $\star \star \star$ & $\star \star \star$ & $\star \star \star$ & $\star \star \star$ & $\star \star \star *$ \\
\hline & & Estimate $95 \% \mathrm{Cl}$ & $65.2 ; 70.3$ & $69.2 ; 78.8$ & $* *$ & $68.7 ; 73.3$ & $62.3 ; 69.2$ \\
\hline
\end{tabular}

BGC, Bacillus Calmette Guérin; DPT, diphteria, tetanus and pertussis; $95 \% \mathrm{Cl}, 95 \%$ confidence interval.

${ }^{*}$ Coverage is $100 \%$

*** As composite coverage index is a weighted measure calculated at the group level, $\mathrm{N}$ is not calculated

FIGURE 3. Coverage for RMNCH indicators according to migratory status and place of residence

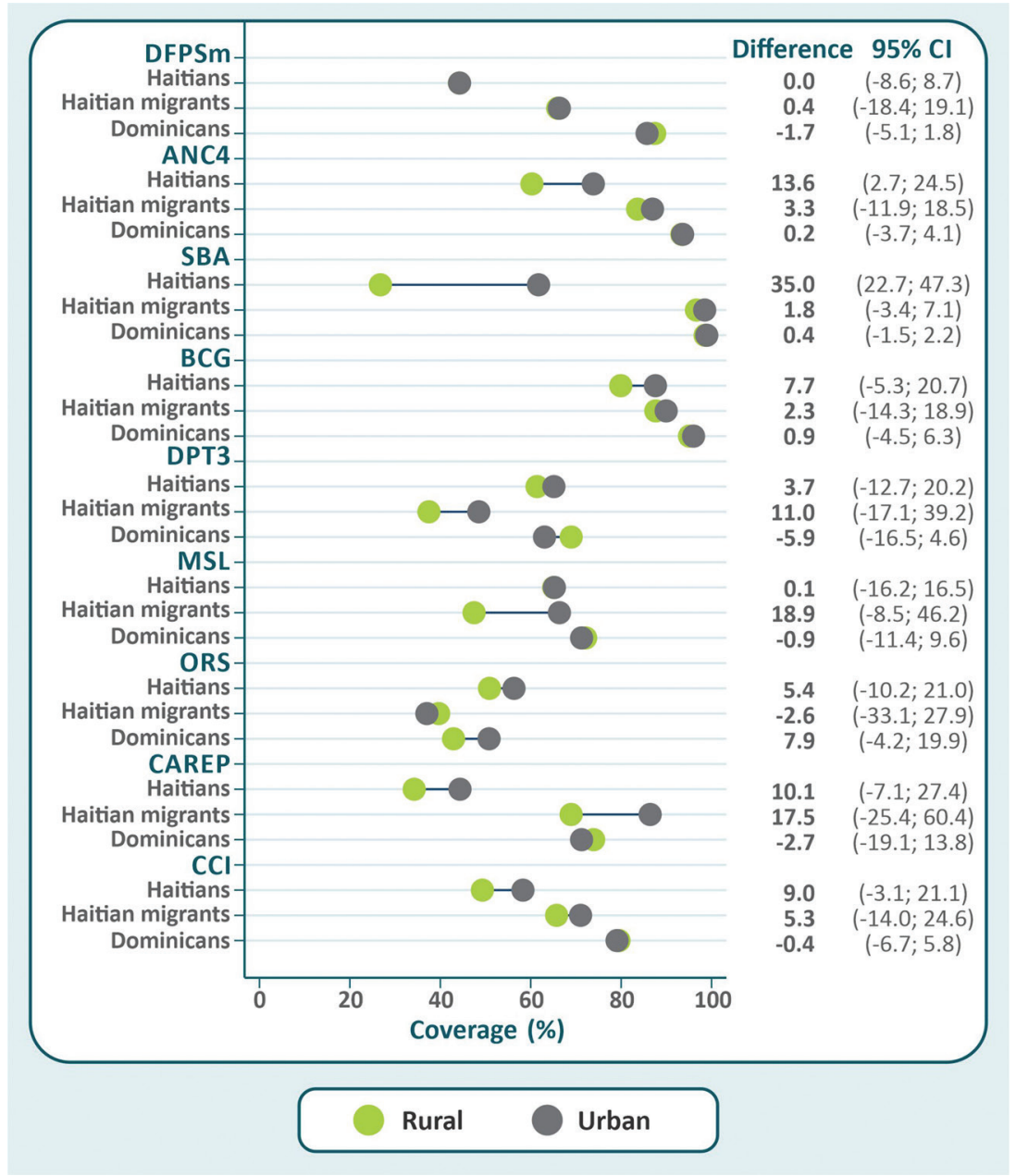

DFPSm, demand for family planning satisfied with modern methods; ANC4, at least 4 antenatal care visits; SBA, skilled birth attendance; BCG, BCG immunization; MSL, measles immunization; DPT3, three doses of DPT immunization; ORS, oral rehydration salts for diarrhea; CAREP, careseeking for suspected pneumonia; CCl, composite coverage index.

Republic. The safety nets described above, which are present in the Dominican Republic, along improvements in other social determinants, may explain why socioeconomic disparities are less marked than in Haiti.

This study has some limitations beyond those already mentioned. Firstly, language spoken by the woman or the head of the household was used as a proxy of migratory status. Thus, it was not possible to differentiate acculturated immigrants, who possibly reported Spanish as their primary language, rather than Creole, from newly acculturated immigrants, considering that there was no information available about the time spent in the receiving country. Yet, the use of language as 
a proxy of migration status is a reliable alternative for population-based surveys (6). The small sample size in some groups is also a limitation. Although the sample size of Haitian migrant women and children was around 1000 individuals, analyses using double stratification by wealth and migration have led to small sample sizes, particularly for indicators related to disease management which are only calculated for children with a recent illness (30).

This study also has strengths. There are few studies of the health effects of migration in low and middle-income countries, as few surveys collect such information (34). The two comparable surveys over a two-year period allowed a comparison of women and children in their countries of origin and of destination. Also, the range of indicators included in the analyses provide a broad and robust overview of $\mathrm{RMNCH}$ coverage (35). Another strength is that the presentation of results respond to Sustainable Development Goal 17.18 which requires disaggregation of the heath and related indicators according to several dimensions of inequality, including migratory status, wealth and place of residence (https://www.un.org/ sustainabledevelopment/sustainable-development-goals/).

\section{CONCLUSION}

The health of the mothers and children are affected by the migratory status of women and children, with Haitian migrants in the Dominican Republic showing better indicators than Haitians who remained in their home country. These results will hopefully contribute to raise awareness among policymakers in the Caribbean region, and particularly on the two neighboring countries, of the importance of documenting the health of migrants, and of stratified analyses to guide the reduction of health inequalities, leaving no one behind.

Authors' contributions. FCW, CV, RB and AB conceived the article. RB and GGD carried out the statistical analyses. MM contributed with the initial data analysis. RB, GGD, DGPL and FCW wrote the paper. FCU, CV, AB contributed with the interpretation of the results. All authors read and approved the final manuscript.

\section{Conflict of interests. None declared.}

Funding. This work was financed in part by the Wellcome Trust Foundation (grant number 101815/Z/13/Z). FCW, AJDB and CGV are productive scholars from the Brazilian National Research Council (CNPq).

Disclaimer. Authors hold sole responsibility for the views expressed in the manuscript, which may not necessarily reflect the opinion or policy of the RPSP/PAJPH and/or PAHO and/or the Federal University of Pelotas.

\section{REFERENCES}

1. Moya J. Migration and the historical formation of Latin America in a global perspective. Sociologias. 2018;20(49):24-68.

2. McAuliffe M, Ruhs M. World migration report 2018. Geneva: International Organization for Migration; 2017.

3. Morrison AR, Schiff M, Sjöblom M. The international migration of women. Washington, DC: World Bank and Palgrave Macmillan; 2007.

4. United Nations Department of Economic and Social Affairs. Trends in International Migrant Stock: Migrants by Destination and Origin (United Nations database, POP/DB/MIG/Stock/Rev.2015). 2015. Available from: https:/ / www.un.org/en/development/desa/population/migration/data/estimates2/estimates15.asp Accessed 11 May 2020.

5. Behrman JA, Weitzman A. Effects of the 2010 Haiti earthquake on women's reproductive health. Stud Fam Plann. 2016;47(1):3-17.

6. Oficina Nacional de Estadística, United Nations Population Fund, Unión Europea. Primera Encuesta Nacional de Inmigrantes en la República Dominicana. ENI-2012. Santo Domingo: ONE/UNFPA/ UE; 2013.

7. Landry V. Feminización y urbanización de la migración haitiana en República Dominicana: una aproximación hacia su caracterización. Rev Pueblos y Front Digit. 2013;8(15):201-24.

8. Petrozziello A, Hintzen A, Díaz JCG. Género y el riesgo de apatridia para la población de ascendencia haitiana en los bateyes de la República Dominicana. Centro para la Observación Migratoria y el Desarrollo en el Caribe (OBMICA); 2014.

9. Hancioglu A, Arnold F. Measuring coverage in $\mathrm{MNCH}$ : tracking progress in health for women and children using DHS and MICS household surveys. PLoS Med. 2013;10(5):e1001391.

10. Boerma JT, Bryce J, Kinfu Y, Axelson H, Victora CG. Mind the gap: equity and trends in coverage of maternal, newborn, and child health services in 54 Countdown countries. Lancet. 2008;371(9620):1259-67.

11. Wehrmeister FC, Barros AJD, Hosseinpoor AR, Boerma T, Victora CG. Measuring universal health coverage in reproductive, maternal, newborn and child health: An update of the composite coverage index. PLoS One. 2020;15(4):e0232350.
12. Rutstein SO. The DHS Wealth Index: Approaches for rural and urban areas. 2008. Available from: https://dhsprogram.com/ publications/publication-WP60-Working-Papers.cfm Accessed 22 November 2019.

13. Rathe M. Dominican Republic: Implementing a Health Protection System that leaves no one behind. Washington DC: World Bank; 2018.

14. Tappero JW, Tauxe R V. Lessons learned during public health response to cholera epidemic in Haiti and the Dominican Republic. Emerg Infect Dis. 2011;17(11):2087.

15. Green R, Miles S. Social impacts of the 12 January 2010 Haiti earthquake. Earthq Spectra. 2011;27(S1):S447-62.

16. Tohme RA, Francois J, Cavallaro KF, Paluku G, Yalcouye I, Jackson E, et al. Expansion of Vaccination Services and Strengthening Vaccine-Preventable Diseases Surveillance in Haiti, 2010-2016. Am J Trop Med Hyg. 2017;97(4_Suppl):28-36.

17. Almeida LM, Santos CC, Caldas JP, Ayres-de-Campos D, Dias S. Obstetric care in a migrant population with free access to health care. Int J Gynecol Obstet. 2014;126(3):244-7.

18. Van den Akker T, Van Roosmalen J. Maternal mortality and severe morbidity in a migration perspective. Best Pract Res Clin Obstet Gynaecol. 2016;32:26-38.

19. Heaman M, Bayrampour H, Kingston D, Blondel B, Gissler M, Roth C, et al. Migrant women's utilization of prenatal care: a systematic review. Matern Child Health J. 2013;17(5):816-36.

20. Keys HM, Noland GS, De Rochars MB, Taylor TH, Blount S, Gonzales M. Perceived discrimination in bateyes of the Dominican Republic: results from the Everyday Discrimination Scale and implications for public health programs. BMC Public Health. 2019;19(1):1513.

21. Schachter A, Kimbro RT, Gorman BK. Language proficiency and health status: Are bilingual immigrants healthier? J Health Soc Behav. 2012;53(1):124-45.

22. Bustamante AV, Fang H, Garza J, Carter-Pokras O, Wallace SP, Rizzo $\mathrm{JA}$, et al. Variations in healthcare access and utilization among Mexican immigrants: the role of documentation status. J Immigr Minor Heal. 2012;14(1):146-55. 
23. Abraído-Lanza AF, Echeverría SE, Flórez KR. Latino immigrants, acculturation, and health: Promising new directions in research. Annu Rev Public Health. 2016;37:219-36.

24. Keys HM, Kaiser BN, Foster JW, Burgos Minaya RY, Kohrt BA. Perceived discrimination, humiliation, and mental health: a mixed-methods study among Haitian migrants in the Dominican Republic. Ethn Health. 2015;20(3):219-40.

25. Ballotari P, D’Angelo S, Bonvicini L, Broccoli S, Caranci N, Candela $S$, et al. Effects of immigrant status on Emergency Room (ER) utilisation by children under age one: a population-based study in the province of Reggio Emilia (Italy). BMC Health Serv Res. 2013;13(1):458.

26. Fox M, Thayer ZM, Wadhwa PD. Acculturation and health: the moderating role of sociocultural context. Am Anthropol. 2017;119(3):405-21.

27. Watson JT, Gayer M, Connolly MA. Epidemics after natural disasters. Emerg Infect Dis. 2007;13(1):1.

28. Walton DA, Ivers LC. Responding to cholera in post-earthquake Haiti. N Engl J Med. 2011;364(1):3-5.

29. Lemonick DM. Epidemics after natural disasters. Am J Clin Med. 2011;8(3):144-52.

30. Barros AJD, Victora CG. Measuring coverage in MNCH: determining and interpreting inequalities in coverage of maternal, newborn, and child health interventions. PLoS Med. 2013;10(5):e1001390.
31. Syed ST, Gerber BS, Sharp LK. Traveling towards disease: transportation barriers to health care access. J Community Health. 2013;38(5):976-93.

32. Perkins J, Capello C, Vilgrain C, Groth L, Billoir H, Santarelli C. Determinants of low maternal and newborn health service utilization in Haiti: a community-based cross-sectional study. J Women's Heal Issues Care. 2017;6:1.

33. Rainey JJ, Lacapère F, Danovaro-Holliday MC, Mung K, Magloire R, Kananda G, et al. Vaccination coverage in Haiti: results from the 2009 national survey. Vaccine. 2012;30(9):1746-51.

34. Victora C, Boerma T, Requejo J, Mesenburg MA, Joseph G, Costa JC, et al. Analyses of inequalities in $\mathrm{RMNCH}$ : rising to the challenge of the SDGs. BMJ Glob Heal. 2019;4(Suppl 4):e001295.

35. Wehrmeister FC, Restrepo-Mendez M-C, Franca GVA, Victora CG, Barros AJD. Summary indices for monitoring universal coverage in maternal and child health care. Bull World Health Organ. 2016;94(12):903.

Manuscript received on 10 July 2020. Revised version accepted for publication on 19 October 2020.

\section{Desigualdades en salud maternoinfantil entre los migrantes: el caso de Haití y la República Dominicana}

RESUMEN

Palabras clave
Objetivo. Evaluar la cobertura y las desigualdades en las intervenciones de salud maternoinfantil entre haitianos, migrantes haitianos en la República Dominicana y dominicanos.

Métodos. Estudio transversal con datos de encuestas representativas a nivel nacional realizadas en Haití en 2012 y en la República Dominicana en 2014. Se compararon nueve indicadores: demanda de planificación familiar satisfecha con métodos modernos, atención prenatal, atención del parto (por personal de salud calificado), vacunación infantil (BCG, sarampión y DPT3), gestión de casos de enfermedad en la infancia (administración de sales de rehidratación oral para la diarrea y búsqueda de atención sanitaria ante la sospecha de neumonía), e índice de cobertura compuesto. La riqueza se midió mediante un índice basado en los activos, dividido en terciles, y el lugar de residencia (urbano o rural) se determinó según la definición del país.

Resultados. La población haitiana mostró la menor cobertura respecto de la demanda de planificación familiar satisfecha con métodos modernos (44,2\%), atención prenatal $(65,3 \%)$, asistencia calificada en el parto $(39,5 \%)$ y búsqueda de atención sanitaria ante la sospecha de neumonía (37,9\%), y la mayor respecto de la administración de sales de rehidratación oral para la diarrea (52,9\%); los migrantes haitianos presentaron la menor cobertura en DPT3 $(44,1 \%)$ y la administración de sales de rehidratación oral para la diarrea (38\%) y la mayor en la búsqueda de atención sanitaria ante la sospecha de neumonía (80,7\%). La población dominicana presentó la cobertura más alta en la mayoría de los indicadores, excepto en la administración de sales de rehidratación oral para la diarrea y en la búsqueda de atención sanitaria ante la sospecha de neumonía. El índice de cobertura compuesto fue de 79,2\% para los dominicanos, 69,0\% para los migrantes haitianos y $52,6 \%$ para los haitianos. Las desigualdades socioeconómicas generalmente tenían un patrón prorrico y prourbano en todos los grupos analizados.

Conclusión. Los migrantes haitianos en la República Dominicana presentaron una mayor cobertura que la población haitiana residente en Haití, pero menor que la población dominicana. Ambos países deberían planificar acciones y políticas para aumentar la cobertura y abordar las desigualdades existentes en las intervenciones de salud materna.

Migración humana; salud materna; salud del niño; disparidades en atención de salud; Haití; República Dominicana. 